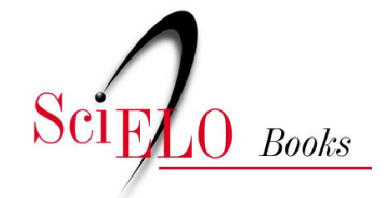

\title{
The Andean Countries
}

\author{
B. Carlos Aguirre
}

SciELO Books / SciELO Livros / SciELO Libros

AGUIRRE, BC. The Andean Countries. In SORJ, B., CANTLEY, M., and SIMPSON, K., eds. Biotechnology in Europe and Latin America: prospects for co-operation [online]. Rio de Janeiro: Centro Edelstein de Pesquisas Sociais, 2010. pp. 171-204. ISBN: 978-85-7582-036-6. Available from SciELO Books $<\underline{\text { http://books.scielo.org }>\text {. }}$

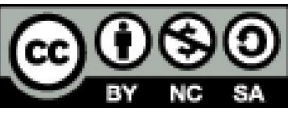

All the contents of this chapter, except where otherwise noted, is licensed under a Creative Commons Attribution-Non Commercial-ShareAlike 3.0 Unported.

Todo o conteúdo deste capítulo, exceto quando houver ressalva, é publicado sob a licença Creative Commons Atribuição Uso Não Comercial - Partilha nos Mesmos Termos 3.0 Não adaptada.

Todo el contenido de este capítulo, excepto donde se indique lo contrario, está bajo licencia de la licencia Creative Commons Reconocimento-NoComercial-CompartirIgual 3.0 Unported. 


\subsection{The Andean Countries}

\section{B. Carlos Aguirre}

\subsubsection{Andean Technology Policy: Its Nature and Far-Reaching Effects}

The Technological Policy adopted in 1969 by the Andean Group (GRAN), was defined to handle the demands generated by the economic integration process, whose goals were: the opening of possibilities to link technology to the building of a large market, the subordination of foreign investments and technology transfer to national and subregional interests and to link technology to the very process of production and services as one of its main factors.

The Andean Technological Policy was an essential element of the idea which tried to assert a process based on domestic habilities, displaying its own capacities and promoting the utilization of local production factors as an important component of an independent development model. Handling problems related to foreign investment, patent rights, technology transfer, information, permitted a step forward to the understanding of the matter. It also made possible to enact new rules on these matters allowing the definition of the action to stimulate technological development.

The Andean Programmes for Technological Development (PADT's) are the tools of the Andean Technological Policy and have become a new experimental area within the GRAN (Andean Group). Thanks to their execution, it was possible to realize that the integration process can take upon itself different co-operative forms to reduce the possibilities of conflict that can arise because of the complementarity that creates them. They lead to the interaction and the union of efforts that outline the Andean Group as a new unit of international co-operation.

${ }^{1}$ This document was prepared for the European/Latin-American Seminar on Biotechnology which, under the auspices of the European Economic Community, held in Brussels, Belgium, between the 27th and 29th April 1987. This document represents the opinions of the authors and does not necessarily reflect the views or opinions of the Cartagena Agreement, nor those of the member countries of the Andean Group. The present document is based on works done by experts of each Andean country, propositions by the Cartagena Agreement to the Andean Council of Science and Technology, and the results of a cooperation programme carried out since 1975.
This instrument eventually became one of the most typical contributions of the Andean Group. As a matter of fact, through their execution it was possible: to constitute multinational teams of experts and technicians; to obtain external financial resources; to reduce the differences among the projects; to exchange specialized information; and, to develop new techniques and methods for technology transfer.

As indicated before, the Andean Technological Policy was steered to demand knowledge from an ambitious project of subregional industrialization and a growing market. However, the far-reaching effects of a joint industrialization were partial and could not cope with the proper characteristics of an incomplete industrialization of the Latin-American region. The enlarged economic space, a key factor for technological development, did not trigger the expected demand of technology.

The strategic scope established by the Technological Policy of the Andean Group intended the combination of many financial, commercial and fiscal elements, but there were multiple divergences among the public powers, and between them and the private sector - a very common problem in the Andean countries. The lack of concertation seriously restrained the complete application of the Andean Technological Policy.

\subsubsection{Guidelines for a Reorientation of the Andean Scientific and Technological Integration}

NEW CHALLENGES

The application of the Andean Technological Policy advanced with the achievements and limitations already noted. In the meanwhile, and after a period of dynamism and growth, the integration process went through phases of stagnation and even regression.

Simultaneously, there is an unprecedented acceleration toward the technological change in the more developed countries, favourable to the upheaval of a new pattern of industrialization which tends to ignore the comparative advantages of developing countries.

On the other hand, as a counterpart to the crisis, the modernization gaps within the countries constitute a great challenge from social, productive and technological points of view. 
In spite of the growing attention placed by the governments of the Andean countries on science and technology, the answers are still insufficient for a National Policy to face problems such as those cited. The new technological elements playing a role deepen the differences between the Andean countries and the more developed countries. The intrinsic weakness of the existing scientific community, the fiscal crisis and the public debt, exacerbates the brain-drain and the dismantlement of the subregion's research centers.

\section{Reorientation of the Scientific and Technological Integration: Bases for a New Concept of Joint Action}

A series of orientations directed to consolidate the obtained results, overcome limitations and face the new challenges at national, sub-regional and international levels, have occurred over the last three years in the Andean Group.

The 'Reorientation Programme of the Andean Integration Process' (1983) contains a conceptual basis that should be mentioned. It points out that integration should offer the countries new prospects and alternatives for their development processes in fields necessitating efforts beyond the national boundaries and, therefore, requiring to be approached by a joint and concerted action. It also underlines the necessity to work with a flexible and pragmatic criterium in order to complete the application of the existing tools with all the possible forms of co-operation leading to a major interrelation among the countries.

Science and technology will help the development of this idea of reorientation. Two central aims are at the base of the new Andean technological strategy:

a) 'To create a joint capacity of scientific and technological response to the challenges of the countries' development and subregional integration process'

The problems, already described, show the advantages of association. The current crisis makes it urgent to unite efforts. In the technological field, it is more and more obvious that isolated positions are insufficient. A joint action is the new support for integration. Besides, scientific and technological co-operation is a must for the
Andean countries, since none of them can establish an independent and viable scientific and technological community.

It is worthwhile to insist here upon the elements of an Andean scientific and technological community. To achieve this, it is imperative to combine human, institutional and financial resources, not only those of the member countries, but also those of an international cooperation.

A pragmatic and urgent effort of permanent harmonization must be made to identify areas susceptible of integration.

b) 'To contribute with science and technology to the carrying out of sectorial strategies for the Andean integration process'

The sectorial strategies for integration enable to identify scientific and technological requirements. From them and through adequate programming and planning, the appropriate mechanisms and instruments to them can be recognized. Among the strategies, the following should be mentioned:

Food safety, within it new prospects for research and application of biotechnology: improved seeds, production of animal vaccines, nitrogen fixation, development of a variety of plants resisting diseases, etc.

Different political decisions give priority to the necessity to develop, appraise and protect renewable and unrenewable natural resources.

On the other side, the industrial sector strategy points out common methods to develop the agro-industry sector. This is due to its potential not only in the expansion of the production of existing goods, but also in the incorporation of new products responding to the basic needs of consumption, and the restriction on imports of final products and basic materials which can be substituted by subregional natural products.

The capital goods sector, a little behind but having a great potential for development in the subregion. It must be taken into account because of its implications on the use of skilled labour, major autonomy of industrial development, commercial potentiality, margin to continue the substitution of imports, and beginning exports on an extended market.

Electronics and telecommunications sector. Because of its numerous links to other areas, such as industry when it results in capital goods, it is one of the 'most promising' themes to work on science and technology. 
Priority is given to the evaluation of potential partners investing on projects for development and production of equipment and the constitution of Andean multinational enterprises.

\subsubsection{Fields of Action of the New Andean Technological Policy}

To reach the enumerated goals, the Andean Strategy for Scientific and Technological Integration has suggested a series of policies focused on fields of action that permit a kind of viable programming, that is to say ready to be applied under Andean realities. The carrying out of these policies should integrate efforts and resources around key matters, and give to the Andean Group a more specific outline when working on science and technology, and using for its development the economic space of the five member countries. Thus, new opportunities are open because of the deliberate utilization of a subregional space for products and sectors carriers of technology.

Three areas of action have been defined and will permit the organisation of the GRAN's efforts on science and technology:

\section{A) MANAGEMENT APPLIED TO THE DEVELOPMENT OF TECHNOLOGICAL} INNOVATION

The lack of an adequate management makes it difficult to apply technology to production. What has been tested is more intuitive than systematic. At present, it is clear that to obtain a real benefit from the research results, it is necessary to combine commercial, financial, etc. market mechanisms, as well as feasibility studies and technology transfer. This stage will require higher expenses. 'The enterprise, in general terms, must play the role of a technological innovation promoter and open the access to more appropriate and modern technologies'. It must be said that without an improvement of the management applied to innovation, no concrete results can be obtained.

\section{B) TECHNICAL AND INFORMATION AREA}

As indicated by the Andean Strategy for Scientific and Technological Integration, one of the areas requiring a major emphasis is the one which will permit 'to collect, process, and offer to the countries technical and economic information at subregional and international levels'... 'to prospect on trends of technical and economic change through branches and products' and 'to support the strategical thought of the subregion'.

Confronted with technical change, it is necessary nowadays to adopt a watchful and prospective attitude, more rigorous, exigent and permanent, as part of the subregional strategy, including the setting up of alternative models for development, taking into account the new technologies and the availability of subregional natural resources. The definition of best elements in order to determine a future technological pluralism, must consider the improvement of traditional technologies.

It has been underlined that 'the creation of information susceptible to support the concrete decisional process, in the pre-feasibility studies, is of vital importance. It requires the combination of structured information on alternative technologies, their economy and their economic conditions of access. This information is not spontaneously available. It must be created. Data must be organized to produce information, and so to say, likely to modify representations and behaviours. The constitution of technical, commercial and economic information must be made at the very foundation of the new activities.

\section{C) Science, Research And Advanced Technologies Area}

The present scientific and technological revolution is influencing multiple aspects of production, health, education and services, which are matters, because of their nature, of great interest for the Andean Group.

The encouragement given to science in the subregion acquires a different perspective. It becomes the condition to assimilate the present current of technological advances. There is talk of an industry based on science. The development of intellectual factors will be the key of competition between countries and group of countries. In the more developed countries, the scientific policy is gaining consideration after a period of stagnation.

In the light of a series of new demands that the sectorial strategies of the Andean Group would lay on scientific and technological areas, it is easy to remark that it is impossible to step forward without a good dose of organization, programming and effective support in the field of personnel training and its utilization through research activities. 
The 'Caracas Programme', approved by Decision 183 of the Cartagena Agreement Commission, claims to fulfill the void on those matters, setting up arrangements and compromises through harmonization and concertation.

A proposition of interest consists of structuring around the Programme a strong supporting movement to the scientific disciplines that serve as a basis for advanced technologies, depending on common needs, that is to say, scientific research and training of personnel.

Therefore, the human resources policy becomes a ruling principle of the Andean strategy as announced at the Cartagena Agreement, '...the unique policy compatible with a shifting future and the dynamics of the technical change, is the training of specialists who should be given a solid scientific knowledge and good practice in research methods. These are the right tools that will enable a fast adaptation to scientific changes, technological innovations and exchange of researchers...'

\subsubsection{The Andean Programme of Biotechnology}

The Cartagena Agreement has promoted since 1986 the programming of the Andean Strategy for Scientific and Technological Integration in concertation with ruling organisms of scientific and technological policy of the member countries, which constitute the Andean Council of Science and Technology.

The new stage, expected to be started in 1987, proposes to re-appraise the meaning of integration, especially its potential economic space, as a means to promote technological innovation within the subregion and to use this process to fortify the Andean integration.

The effort displayed till now to structure the Andean Programme of Biotechnology is an important part of the framework. To this purpose, there are national and community experiences, which will be analyzed in this document.

In general, the programme will try to organize joint capabilities on Biotechnology, especially in areas of social and economic interest to the Andean countries, such as the agriculture, health and food safety areas.

In the management area of biotechnology innovation, the programme will include financial incentives and a growing market. These actions allow the promotion and establishment of Andean multinational enterprises or similar forms of association, with the participation of the private sector and research institutes. Special attention will be placed on problems such as technology transfer and intellectual property.

The programme must consider the degree of advancement of the results already obtained in the Andean countries. Information on opportunities and sources, where a subregional action is advisable, will be collected and analyzed. The programme's basic activity is the analysis and evaluation of economic, technical and commercial information.

An immediate requirement is to promote the education and training of personnel research techniques. The establishment of networks and specific projects of $R \& D$ is part of the initial effort to identify requirements and common means for training.

\subsubsection{National and Subregional Experiences}

\section{NATIONAL EXPERIENCES}

The outline of the Andean Programme of Biotechnology is based on the experience of each member country in the biotechnology field.

At national level, there is a group of important activities in execution or planned at short or middle term, not only to formulate policies but also programmes and projects.

BOLIVIA

The development of biotechnology in Bolivia has not so far reached the level of the other countries of the subregion. However, at the Academia Nacional de Ciencias and the Universidad Boliviana, there is a group of researchers working together with those of the private sector, which constitute the basis on which a short-term nationwide programme is being discussed.

It is convenient to indicate as background that various efforts have already been displayed to establish a critical mass of re-searchers on which the programme will be based on.

Particularly, the activity developed by the National Co-ordination Committee for the development of biological sciences, has increased the scientific level of experts on biology through national and international courses and lectures, fellowships and training. At present, there are in Bolivia experts concentrated mainly at Instituto de Genética Humana, founded in 1972, Instituto de Investigaciones Biológicas of the Academia 
Nacional de Ciencias, founded in 1961, Department of Biology of the Universidad Mayor de San Simón and at the Facultad de Bioquímica y Farmacia of the Universidad Mayor de San Andrés.

At the industrial sector level, the pharmaceutical industry, although in the initial phase of formation has an important potential within a reduced number of national laboratories: INTI, VITA, ALCO, SIGMA and others, which have a high technological level. In the pharmaceutical field, Bolivia can develop biotechnology for the production of antibiotics through available natural resources.

There is also an important potential for biotechnology development and its application on farming. On the other hand, within the framework of a subregional project, Bolivia acquired important experience in the application of biotechnology to the mining and metallurgical sector.

Within the framework of policies and strategies for the development of the biotechnology programme, the Academia Nacional de Ciencias of Bolivia proposes to prepare the right ground for the management of a larger international co-operation, both regional and North/South, according to the programmes previously developed by CONDECIB and enlarged with new specific projects, which will integrate the scientific development sectors to productive areas of the nation.

The specific projects will constitute a coherent whole through which products and services of national and subregional interest will be obtained. They will contribute to the development and strengthening of science in the country and the Subregion.

The basic activity of these programmes or subprogrammes will be made up of specific projects for research and development of products and services. The programmes will be carried out by means of subcontracts between both the ruling and the executive organisms.

In its initial phase, the programme will analyze the establishment of an information network, the development of legal tools permit-ting the protection of the obtained results, and the organization of biotechnology laboratories so as to increase the interactions among them.

The general goals of the programme will be: a) To promote integration and links among the activities to be developed on biotechnology in the country, allowing the technological advance for development, implementing the definition and execution of biotechnologies and supporting the definition and execution of joint actions in order to find solutions to local and regional priority problems, through the obtainment of process products and services.

b) To generate projects of regional interest, which will permit the obtainment of international funds in order to try to solve the problems which action will have to face within the national borders, giving a remarkable social and economic impact enabling to clear up and solve problems through biotechnology techniques.

c) To develop diffusion and demonstration mechanisms directed to both state-controlled and private companies in order to promote investments.

d) To fortify the scientific and technological infrastructure of the country in order to carry out the programme for the benefit of Bolivia.

Regarding present research work in Bolivia, the Instituto de Genética Humana is carrying out a research programme, sponsored by the O.E.A., on Americanae Camelidae with the objective to implant vicuna embryos in llama uterus.

Another programme, in execution at the present time, is molecular biotechnology on diarrhoea diseases (enteropathy) and the transmission of viruses; to combat the drug resistance of the pathogenic strains through plasmids.

The Instituto de Biologia of the Academia Nacional de Ciencias, is carrying out a study on the neurobiological effects of snake venoms, and later, will prepare serums and vaccines.

COLOMBIA

The National Programme of Biotechnology set up by COLCIENCIAS endeavors the creation of a working mechanism with a high degree of participation and consultation with both the scientific community and the national productive sector. It also attempts the establishment of relations of active exchange and co-ordination with other countries of the region which have similar problems as those of Colombia, and also with countries in 
which biotechnology is well developed, marking the international trends whose social and economic impact must be analyzed and made known at the right time.

The basic activity is the permanent evaluation of the programme's progress, the redefinition of its objectives and priorities in accordance with the results, new trends, identification of needs, studies of feasibility and new opportunities.

The programme's basic activity as well as the whole series of necessary and essential activities for its perfect development, must rely on sufficient financial and human resources besides a definitive planning in order to reach the objectives. For this reason, each one of the essential activities has been structured as a subprogramme defined with concrete and specific goals and its proper order of priorities to give an answer to the needs of the Nationa1 Programme.

Another of the Programme's essential actions, already structured as subprogramme, is the establishment of an interaction between the productive sector and the scientific and technological sector. To fulfill this requirement it is necessary to undertake an aggressive policy of reciprocal diffusion between both sectors by means of a series of seminars attended by international experts, and later on, to promote activities resulting in an effective transfer of knowledge, technique, methods and services between the sectors above mentioned.

Concerning the international relations, the corresponding subprogramme promotes the exchange with outstanding centres, binational and multinational projects which encourage the national research activity, courses, congresses, and any other scientific meeting in order to satisfy specific needs of the research groups; organizes and diffuses any information received from abroad and from international organisms to the scientific community of the country; establishes contacts with technical missions of the embassies and, through them with other science and technology organisations of the countries represented; and keeps an active relation with regional and international programmes on biotechnology.

Up to now, the following activities have been considered as necessary for the efficient execution of the research projects:

a) Training of human resources. b) Establishment of a scientific and technological information and documentation network.

c) Setting up and running of a system of evaluation and control of the programme's development and other projects.

d) Monitoring and analysis of world-wide development trends of biotechnology, and anticipation of its economic impact.

e) International relationships and regional integration. Co-ordination with other national programmes.

f) Setting up and running of communication mechanisms between both the scientific and technological and the production sectors. Encouragement of a university/industry co-operation.

g) Enterprise management and development.

h) Projects for scientific and technological development.

i) Economic projects

Each one of the activities mentioned above will give their support to research projects. The activities have been chosen after consultation with the scientific community and some representatives of the national productive sector according to the country's needs and priorities and the presence of active groups in the different areas (see Chart 1).

The establishment of priorities for the development of biotechnology products and their production at commercial level, should be based on detailed economic surveys and on the predominating needs of the country and region. Studies envisaged by the National Programme will start soon.

However, there are certain product lines and services unquestionably essential because of their strong demand or immediate application and, therefore, receiving financial support from COLCIENCIAS through specific projects for development and research, which will be at short and middle term the object of negotiations for technology transfer and adaptation.

These lines are: development of vaccines; production of antigens, monoclonal antibodies, diagnostic kits for tropical diseases; plant micropropagation through tissue or cell culture; improvement of the symbiotic and asymbiotic fixation process of nitrogen in plants; biodegradation of organic polluants; recovery of biogas and biofertilizers; production of single-cell proteins for animal feed; production of enzymes for industrial use, lactic starters, organic acids and antibiotics. 


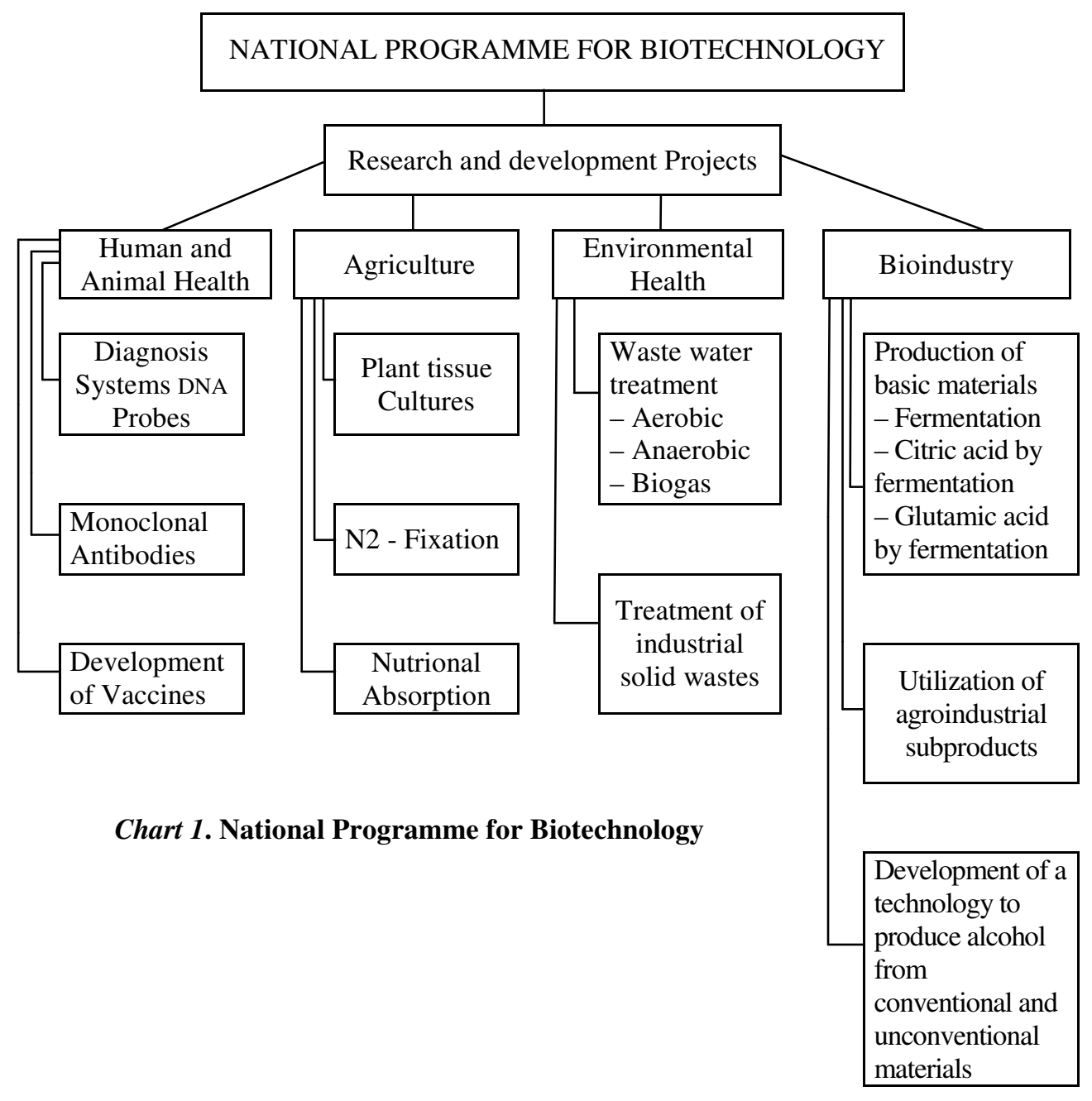

In the middle-term, there are also, at nation-wide level, projects with significant economic prospects such as: the animal reproduction through genetic techniques; the production of hormones, diagnostic kits for plant viral diseases, secondary metabolites from plant cell cultures, biopesticides for the biological control of epidemics, and bacterial leaching processes of certain metals.
ECUADOR

The National Council of Science and Technology (CONACYT) has promoted activities on biotechnology since 1983. At the very beginning an advisory group was created, composed of researchers of institutions working in biotechnology fields.

This group has helped to define priority areas and research projects which need to be developed. On the other side, it has supported the analysis of propositions made by international organisations, which have urged the country to adhere to development programmes on biotechnology. In the policy guidelines proposed by CONACYT, biotechnology is considered as a scientific and technological priority to solve some of the serious problems the country is facing, taking into account the unprecedented development of this sector at international level.

The policy guidelines will be concretized in a National Plan which, on the one hand, will gather the activities developed in the "Grupo Ecuatoriano de Biotecnologia' and, on the other hand, will determine actions directed to the production, application, adaptation and diffusion of biotechnology in the agro-food and industrial production; and will also attach health and environment preservation problems.

The National Plan for Biotechnology Development will contain harmonized programmes as part of the actions to be carried out in order to reach objectives and goals.

Among the planned programmes, the following ones can be mentioned:

a) Manpower Training Programme, through which a review and harmonization of the study plans on the basic sciences will be done at medium and high levels. It will support and fortify the disciplines of basic sciences in order to provide a basis for the training of human resources in biotechnology, such as: cellular biology, molecular biology, biochemistry, biophysics, virology, enzymology, genetics, microbiology and immunology, at postgraduate level. It will permit the identification of Master and Ph.D. programmes on biotechnology, which will be followed by Ecuadorian experts, in the countries of the region and in the developed countries. 
b) Research and Development Programme, through which the following points will be carried out: the evaluation of scientific and technological potential; the survey of research needs on biotechnology, giving priority to research Unes; identification of research projects on biotechnology which could be carried out by combined action of both the university and the industry; backing the foundation of a Biotechnology Research Centre whose objective will be, on the one hand, to stimulate the execution of research projects on problems of social interest, encouraging sectorial biotechnology production, and, on the other hand, to enrich the manpower training programmes and provide technical advice on governmental decisions; supporting research projects planned by institutions and research centres, which are presently developing surveys.

c) Programme to encourage international and technical co-operation, aimed to fortify the participation of the country in research projects on biotechnology, at regional and international levels.

From a strategical point of view, CONACYT intends to defineate the scientific and technological policies in the sector and the National Plan, suitable for being applied to the country's conditions and according to the evaluation of the scientific and technological potential, in co-ordination with the 'Grupo Ecuatoriano de Biotecnologia', which should be changed into a Technical Committee.

Concerning the research at present on execution, see Chart 2. Besides, the following institutions of public and private sectors are developing research, some of them at industrial and semi-industrial levels:

- Instituto Ecuatoriano de Investigaciones Agropecuarias: Merismatic Culture.

- Instituto Nacional de Higiene: production of human vaccines.

- INEXA S.A.: merismatic cultures.

- Latin-ReCo S.A.: food production.

- PRONATEC S.A.: Natural extracts.

- Centro de Adiestramiento Lechero S.A.: Lacteal fermentations.

- LEVAPAn S.A.: Development of fermentation processes.

- Laboratorios farmaceuticos Ecuatorianos (LIFE) S.A.: Production of animal vaccines.

- ALCOLESA S.A.: Alcoholic fermentation of molasses.

\begin{tabular}{|c|c|c|}
\hline \multicolumn{3}{|c|}{ Chart 2. Current Projects } \\
\hline Institution & Executive unity & Research fields \\
\hline $\begin{array}{l}\text { Universidad } \\
\text { Central del } \\
\text { Ecuador }\end{array}$ & $\begin{array}{l}\text { Faculty of } \\
\text { Medical Science }\end{array}$ & $\begin{array}{l}\text { - Histocompatibility } \\
\text { - Immunology and infections } \\
\text { - Development of Bioreactors } \\
\text { - Purification of plant dyes } \\
\text { - Purification of fuels }\end{array}$ \\
\hline $\begin{array}{l}\text { Universidad } \\
\text { Tecnica }\end{array}$ & $\begin{array}{l}\text { School of } \\
\text { Chemical } \\
\text { Engineering }\end{array}$ & $\begin{array}{l}\text { - Fermentation in solid material } \\
\text { - Dairy technology } \\
\text { - Meat technology } \\
\text { - Fruit and vegetable technology } \\
\text { - Post-harvesting studies of perishable } \\
\text { products }\end{array}$ \\
\hline $\begin{array}{l}\text { Universidad de } \\
\text { Guayaquil }\end{array}$ & $\begin{array}{l}\text { Faculty of } \\
\text { Natural } \\
\text { Sciences }\end{array}$ & $\begin{array}{l}\text { - Larval development of Macrobrachium } \\
\text { penamensis } \\
\text { - Sexual maturing of Bocachico (Bocaccio) } \\
\text { - Sexual diphorism and reproduction of } \\
\text { Aeuides mivulatus, in aquaculture } \\
\text { - Culture of Mytella guyamensis mussel } \\
\text { - Phytoplankton culture } \\
\text { - Sellfish of commercial interest }\end{array}$ \\
\hline $\begin{array}{l}\text { Armada del } \\
\text { Ecuador }\end{array}$ & $\begin{array}{l}\text { Oceanografic } \\
\text { Institute } \\
\text { (Division of Sea } \\
\text { Sciences) }\end{array}$ & $\begin{array}{l}\text { - Sea phytoplank and primary production } \\
\text { - Sea zooplankton } \\
\text { - Sea Benthos }\end{array}$ \\
\hline
\end{tabular}

In order to accelerate the biotechnology development, it is required, on the one hand, to encourage the training of human resources, strengthening in this way the country's scientific level through postgraduate courses in the countries of the region and the developed countries, and, on the other hand, to set up a teaching and permanent research programme at under- and postgraduate levels for the education and training of national researchers.

On that account, it is expected in Ecuador to initiate in 1988 the postgraduate programme on molecular and cellular biology as basic sciences in order to develop biotechnology.

At last, research projects to be carried out in the middle term are:

- Pharmaceutical products: Nation-wide development of the industrial production of pharmaceuticals; study of plant active principles and 
their application in the pharmaceutical industry; 'in vitro' production of antibodies from hydridoma to determinate: a) bacterial and viral antigens through etiopathogenic studies in animals; b) vaccine production from characterization of surface antigens; c) detection of blood markers of malignity for diagnosis of tumoral diseases; d) therapy methods using monoclonal antibodies finked covalently to drugs in order to attach malignant cells.

- Food products: Liquid and solid fermentations for the production and industrial transformation of food; in high-protein food, it is planned to carry out genetic modifications of the quinoa to increase its nutritive value; microbial culture collections: implementation of a microbial culture collection for the maintenance and distribution of strains of industrial interest; aquaculture: culture of sea organisms to improve production and nutritive value of shrimps, oysters and fish; biomass processes: production of biomass to obtain animal feeding-stuff biological control of insect vectors: studies of molecular biology, cellular biology and cytogenetics for the control of the life cycle of insect transmitters of malaria, oncocercosis, trypanosomiasis; plant culture: production of vegetable clones to obtain plants with high productivity and higher resistance to diseases.

- Genetic engineering: Interferon production for the treatment of cancerous diseases. Diagnosis of hereditary diseases through recombinant DNA techniques.

- Environment pollution: Treatment of industrial wastes, especially waste waters.

PERU

In 1986, the Peruvian National Council of Science and Technology (CONCYTEC) created the Consulting Commission of Biotechnology to analyze and propose activities for the application of biotechnology in the country.

Peru is far away from having a critical mass of researchers in this field. The country requires an adequate co-ordination of the international organization and the existing research activities for the development of this field allowing it to reach the phase of goods and services production and to improve the standard of living of the population.
In Peru, there is a deep gap between the industry sector and the universities; that is why initial actions of mutual benefit should be started, and whose quality and quantity would be gradually improved and increased. On that account, the teaching centres could offer quality control and advisory services, permitting an ever growing exchange and a real activity of co-operation in the future. A possible form of this co-operation is the establishment of industries which, rooted in academic institutions, can benefit from the human resources, equipment international advisory and consultancy available for those institutions, and contribute to their entire work on teaching, research and services.

An important aspect to be considered for the development of biotechnology in the country is the manpower training. In this direction, the National Programme must first contemplate the strengthening of different systems of advanced education (postgraduate courses, professional specialization, training, etc.), as well as trainee researcher exchange and the utilization of international and regional co-operation for that purpose.

The Consulting Commission of Biotechnology considers four sectors in which the application of biotechnology in Peru is of great importance:

Biomedical and Veterinary Sector. There are good reasons to back the biotechnology development in the health sector. The programme embraces promising technologies, of fast development, not requiring large investments for their implementation, depending on the existence of a critical mass of skilled specialists, and could be established in the present centres wherein biologists, chemists, pharmacists, veterinarians, biochemical physicians, microbiologists, immunologists and other researchers are educated and further trained.

It is likely to aim to a nation-wide production of diagnostic elements of biotechnological origin that will substitute, more or less quickly, expensive culture techniques and for which basic material is still imported.

With regard to therapeutic products, agreements could probably be concluded to ask national companies to take upon themselves the production and commercialization of bioproducts and to assume the development and production of products according to the needs in the near future.

Concerning vaccines, the World Health Organization and the PanAmerican Health Organization, working jointly with National Institutes of 
other American countries, will probably offer consulting services, support the technological development, set up production lines, quality control, etc. The areas of major interest are the following:

- Diagnosis of enteropathy, tuberculosis, acute respiratory diseases, transmitted by vectors and parasites;

- Thermostable vaccines and new vaccines;

- Other biological products such as antidotes, insulin and plasminogen activator.

Agro-Food Sector. This is a prior-right sector because of the agricultural situation of the country.

In several points of this sector, the in situ application of biotechnological processes is feasible, which could incite the development of rural industries, with a very large social impact. The application of these processes would also increase the production and productivity of the land. However, the promotion of a biotechnological agriculture will require a good control of its production and an appropriately expanded work from the corresponding governmental organisms.

In the agro-food sector, there are already some experiences and preliminary results which should be encouraged for obtaining short-term success, including their transfer to other countries of the region. Experiences and results within the following areas:

1. in vitro cultures;

2. micropropagation and genetic stabilization of plants;

3. production of basic seeds;

4. bioconversion of materials and agro-industrial wastes into animal

5. feeding stuff, enzyme production, alcohols and other chemical substances;

6. production of biogas and biofertilizers;

7. nitrogen-fixing micro-organisms and mycorrhyzal fungi;

8. production of diagnostic systems for plant viruses.

Chemical and Pharmaceutical Industry Sector. Considering the import balance of basic materials for the chemical and pharmaceutical industries, it is essential to substitute imports and to develop the following areas:
1. alcohol production as raw material for chemical industries (chemistry of alcohols);

2. production of solvents (butanol, isopropanol, acetone, etc.);

3. production of antibiotics through fermentation and biosynthetic methods (penicillins and semi-synthetic cephalosporins, aminoglycosides and rifampicin);

4. production of organic acids (citric, acetic, lactic, fumaric and others);

5. production of essential amino acids (lysine, methionine and glutamic acid) and vitamins (riboflavin and ascorbic acid);

6. production of steroids (cortisone, prednisone) and other molecules obtained from yams;

7. production of alkaloids and other substances through vegetable cell cultures.

Other Sectors. The following four areas are important:

1. metal extraction from metallic sulphates through bacterial

2. leaching;

3. tertiary recovery of petroleum

4. biodegradation of pollutants;

5. monitoring of environmental pollution.

Generally speaking, it is extremely important to carry out in these sectors a national evaluation of economic, political and technical nature.

In order to set up a programme, the Consulting Commission has proposed:

a) To carry out an evaluation of the national biotechnology, developing its prospects.

b) To analyze biotechnology abroad at three levels: Developed Countries, Third World Countries, the Andean Countries.

c) The elaboration and regulation of a policy responding to a national demand and adjusted to the situation of the country, in order to reach results enabling the improvement of the standard of life of the Peruvian consumer. The regulations must include a 'Patent Register' for the protection of biotechnological processes which do 
not have a directly human and social incidence, and, of course, underline the priority of working areas.

Besides the Commission has proposed:

- To create a National Network of Biotechnology as an institutionalized system of co-ordination and intercommunication, in accordance with the existing national laboratories.

- To recommend the creation of a special fund for biotechnology research and development, giving to the ITINTEC a part $(2 \%)$ of the resources provided by the industry, and thus harmonize research teams, activate the laboratories of the National Network and encourage researchers. This fund would be managed by the CONCYTEC.

- To promote meetings and communication among entrepreneurs, researchers and users of biotechnology to make effective the utilization of the National Network.

- It is necessary to clarify to what extent basic materials and scientific equipment, essential for the development of biotechnology, represent a significant point in the Peruvian import balance. A strategy must be planned to put an end to this dependency in order to develop the national production of these basic materials and scientific equipment.

- The permanent problem of imports has also been discussed. By general consent, CONCYTEC should try to speed up the regulations concerning customs clearance so as to be able, at least, to receive radioactive materials with preserved good specific capacity, really fresh biochemical supplies, laboratory reactives, biologically active and special strains.

\section{VENEZUELA}

The National Programme of Biotechnology was set up in 1984, after the President of the Republic created by Presidential Decree No. 240 the National Commission for Genetic Engineering and Biotechnology, within the National Council for Scientific and Technological Research, to act as an advisory organism to the presidency of the Republic and to define policies and elaborate plans for the development of genetic engineering and biotechnology.

The Programme's main objectives are the following: a) To promote scientific and technological research in genetic engineering and biotechnology areas.

b) To formulate and co-ordinate the National Plan for Genetic Engineering and Biotechnology.

c) To co-operate with organisms whose task is to promote, plan and finance the scientific and technological development of the country in this area.

d) To attempt the establishment of scientific and technological networks of information on genetic engineering and biotechnology.

e) To spur the training of human resources in this area.

f) To co-operate with organisations which represent the Republic on international matters; especially when relationships in the biotechnology area are concerned.

With the aim to get the Programme started, a strategy has been adopted to sort out projects, including the establishment of research cooperative groups in agriculture, agro-industry, and medicine areas, in which the participation of the teaching and the industry sectors is expected.

The principal projects of the biotechnology Programme, already selected, are the following:

Agriculture. Production of potato and yucca mother plants and other products, through tissue culture techniques, somatic hybridization, induction and selection of mutants.

Obtainment of pathogen-free plants using tissue culture techniques, followed by massive clonal propagation and development of diagnostic reactives for pathogen detection.

Industry. Purification technology of glucose and fructose syrups. Design and evaluation of processes for the production of fructose syrups.

Agro-industrial waste recovery for the production of protein-rich animal feed.

Enzymatic degradation of lignocellulose wastes.

Biomedicine. Studies of diagnosis, prophylaxis and epidemiology of diseases such as: leishmaniasis, trypanosomiasis and leprosy. Research in 
this field will include pathogen isolation and culture, cloning and antigen identification, obtainment of monoclonal and polyclonal antibodies, etc. Biochemistry and immunology studies are also planned.

Another group of studies in this area are: Cancer and AIDS diagnosis, therapeutics and epidemiology. Research in this area could be aimed to gene isolation, recombination, production of RNA and DNA probes, oncogens, transformation factors, etc.

SubregionAl ExPERIENCES: PADT-COBRE AND THE MINING-

MEtallurgicAl Programme

The Commission of the Cartagena Agreement, by Decisions 86 and 87, approved the Andean Projects for Technological Development in the Copper area (PADT-Cobre), whose activities started in 1973 and came to an end in 1981. The general objectives of PADT-Cobre were the following;

a) To form specialists teams, competent enough to generate and improve technologies applied in the area, from laboratory level to the planning, design, maintenance and operation of industrial plants.

b) To create in Bolivia and Peru laboratory facilities for the analysis, evaluation and development of existing studies on leaching of copper ore.

The projects executed within the PADT-Cobre framework, in which Peru and Bolivia participated, were:

Project I: Copper-oxide ore treatment through leaching with sulphuric acid and cementation with scrap iron.

Project II: Bacterial-acid leaching of copper ore in columns or wastes.

Project III: Copper recovery from copper sulphate solutions through ionexchange electro-deposition.

NOTEWORTHY RESULTS IN BOLIVIA

a) Equipment, fitting up, and operation of the laboratory belonging to the Department of Special Metallurgical Projects of the SubDirection of Projects of COMIBOL, in Oruro.

b) Fitting up of the Krupp pilot plant type 11 for copper recovery through ion-exchange electro-deposition. c) Education and training of 23 specialists, among them engineers and technicians on acid-leaching technologies; and, on the planning, design, building and operation of pilot and industrial plants for copper treatment through hydrometallurgical methods. This technical team has up-to-now elaborated two studies of feasibility 'Corocoro' and Solivar', and two of pre-feasibility 'San Miguel' and 'Telemayu'.

Noteworthy Results IN PERU

a) Equipment, fitting up and operation of the laboratory of the Department of Metallurgy Research of CENTROMIN, in La Oroya.

b) Plan, design, fitting up and operation of the Pilot Complex of Toromocho which is composed of 8 copper ore columns with more than 150,000 MT, reaching, some of them, an extraction rate of $88 \%$ and a throughput of $3.5 \%$ per month; a cementation plant of nearly 15 MT per month; and a Krupp plant for ion-exchange electrodeposition with a capacity of 14 MT of electrolytical copper per year. Approximately 400 MT of copper cement (worth US $\$ 470,000$ ) were produced in the cementation plant.

c) Education and training of 35 specialists, among them engineers and technicians, of CENTROMIN Peru, Ingemmet and Minero Peru.

In general, the following concluding remarks can be mentioned:

a) The development of PADT-Cobre has permitted the utilization of technologies in the copper hydrometallurgical area applied to the benefit of lower-grade copper ore in the following areas: chemical leaching, ferro-bacterial leaching, extraction by solvents, cementation, electro-deposition and crystallization.

b) As a result of the above mentioned development, technical and economic studies have been worked out, such as the planning, design, building and operation of the Pilot Complex of Toromocho in Centromin Peru.

c) The mastering of the technologies developed in Bolivia and Peru will enable their incorporation to the industrial and productive sector of both countries. 
d) The utilization of technologies developed in the subregion in the near future will allow the incorporation and development of new sources of foreign exchange. At the same time, they will have a growing effect, which will permit a larger industrial activity and the creation of 'satellite' services parallel to the establishment of new technologies.

e) The technological achievements attained through the concerted effort of the Cartagena Agreement and the Member Countries, in the present case Bolivia and Peru, are a clear example of what can be reached by means of a clearly defined technological integration policy provided with mechanisms and tools for its efficient application.

f) The adopted technologies open the way to recover copper and other valuable metals from lower-grade ore constituted by out-falls, effluent residues, wastes, etc. Two million tons of lower-grade ore has been estimated in Peru and Bolivia. The acquired technological knowledge will permit not only a more important income for both countries, but also a great contribution to fight environmental pollution provoked by traditional mining methods.

On basis of the experience above described, the Cartagena Agreement began in 1985 the development of the Andean MiningMetallurgical Programme (PMMA), whose general objective is to strengthen the technical and economic integration of the mining-metallurgical sector of the Andean subregion.

Particularly in the bio-hydrometallurgical area, work is at present carried out on technology transfer of bacterial leaching, obtained during the PADT-Cobre, and its application for polymetallic extraction. On the other side, research on the application of other hydro-metallurgical technologies, which will permit the recovery of other metals, is on the way.

These activities are possible because of the consolidation of the research and application centres for this technology in the Member Countries, and of course the training of human resources.

The technologies constituting this programme, will be applied in deposits chosen by the Member Countries.
With regard to financing, it is necessary to indicate the support for technical co-operation, not refundable, from the government of the Federal Republic of Germany, thanks to an accord with the Cartagena Agreement.

The ANDEAN CounCIL FOR SCIENCE AND TECHNOLOGY AND THE CONCERTATION OF ACTION ON BIOTECHNOLOGY

The Andean Council for Science and Technology (CACYT) strives to promote, at subregional level, an adequate scientific and technological capacity to satisfy the demands for economic and social development of the Member Countries (Decision 213).

The CACYT is composed of top authorities responsible, in each one of the countries, for the scientific and technological system and the orientation of activities considered in the 'Caracas Programme for Co-operation on Research and Scientific and Technological Education and Training' (Decision 183).

During its second meeting (La Paz, 1984) the CACYT recommended to enter upon biotechnology all together, and also sup-ported the creation of a work team composed of Colombia and Venezuela in order to elaborate preliminary actions, initiating a process of concertation and programming.

To achieve its goal, this task took form at the 'Cucuta Meeting', celebrated between both countries in September 1986; further details will be given in the next section.

Another source of discussion for concertation on biotechnology during the Fourth CACYT (Caracas, 1986) were the topics identified in the national plans for Science and Technology, by means of a document prepared by the Cartagena Agreement.

The Fourth CACYT adopted the idea of 'problem-areas' in order to identify action lines and to programme, at the first phase, joint activities on biotechnology.

In the health area: Tropical diseases, malaria, Chagas' disease and leishmaniasis were considered as targets for biotechnology applications.

In the agriculture area: The improvement of productivity through nitrogen fixation and micropropagation of pathogen-free plants were considered as priority lines. 
In the agro-industry area, priority was given to the improvement of nutrition through the production of protein-rich food.

In the natural resources area, an adequate utilization of natural resources will allow work on biotechnological research, and especially in fields related to promising products, treatment of waters and wastes.

In the energy area, the development of new sources, such as those generated by biomass, was considered as a priority for the first stage.

The Fourth CACYT recommended that the programming of scientific and technological activities on action lines above mentioned, must arise from the necessity to link research and production, and to take advantage of the Andean growing market to boost intensive products in technology, and fixing the financial mechanisms to obtain them.

\section{The Colombo-Venezuelan Meeting on Biotechnology in Health} AND AGRICULTURE AREAS

The Colombo-Venezuelan Meeting on Biotechnology in the health and agriculture areas, sponsored by the CACYT, was held between the 18th and 20th September 1986. Delegations of each Member Country presided by the top governmental authorities on scientific and technological policy, the Ministry of Science and Technology of Venezuela and the Director of Colciencias. Representatives of the Cartagena Agreement, EEC and BID attended the meeting too.

The participants contributed to the elaboration of specific project outlines intended to apply biotechnology in the health and agriculture areas through the creation and support of a series of co-operative networks to which other Member Countries would be later invited to participate in (see Chart 3).

The Programme's main objectives will be the expansion of the scientific and technological capacity on biotechnology and the potential market for the products resulting from its application; obtainment of products and services of significant economic and health interest for the subregion; and the co-operation on education and training of human resources to attain these goals.

\section{Chart 3. The Cucuta Meeting: outlines for specific projects \\ Biotechnology on Health}

Project I Leishmaniasis

Utilization of biotechnology for the development of detection techniques of leishmaniasis. Subprojects

1. Standardization and production of leishmania for diagnosis and prognosis of leishmaniasis.

2. Employment of DNA probes for identification and classification of leishmaniasis in vectors, for epidemiological control.

3. Use of monoclonal antibodies for identification, diagnosis and prognosis of leishmaniasis.

4. Isolation and characterization of specific antigens of leishmaniasis for diagnosis

Project II Creation of New Techniques for Diagnosis of the Chagas' Disease

Project III Diagnosis of Malaria

Subproject A: Entomological diagnosis.

Subproject B: Human blood cell screening.

Project IV. Animal Health

$$
\text { Subprojects }
$$

1. Bacterial and viral agents affecting bovine reproduction, brucellosis, bovine viral diarrhoea, bovine rhinotracheitis.

2. Hemoparasites, babesia and anaplasm.

3. Vesicular diseases, vesicular stomatitis and foot-and-mouth disease.

4. Viral agents provoking diarrhoea in porcines, bovines (rotavirus, reovirus).

5. Viral agents affecting poultry raising.

\section{Biotechnology on Agriculture}

Project I Tissue Culture

Subprojects

1. Selection and programming of promising banana clones of regional interest for Colombia and Venezuela.

2. Production of healthy potato plants for sowing.

3. Development of methodologies for clonal propagation of cacao.

4. Development of a technology for pelleting embryos produced 'in vitro'.

Project II Diagnosis and Prevention of Viral Diseases in Food and Industrial Cultures

To that effect, it has been suggested the creation of an integrative programme embracing the different aspects of co-operation in the area, and precluding the arise of a package of independent specific projects. A twofold objective is in mind to face mutual deficiencies which would hinder the 
success on the intended projects, and allow the introduction of new products as soon as areas of interest for regional concertation are detected. The programme will probably last four years in order to enable the harmonization of the goals fixed in projects initially chosen and those which could be introduced in the programme's first stage.

The programme is subdivided in three subprogrammes: (a) human health; (b) animal health; (c) education and training of human resources and scientific exchange. The first two subprogrammes embrace a series of specific projects in their respective areas. Priority was given to these projects because of the available information in the First ColomboVenezuelan Meeting on Biotechnology, but the introduction of projects for co-operation by well-known laboratories in both countries in areas not considered within the first stage, will be accelerated.

Every financed project will be directed by a co-ordinator appointed by the heads of the participant laboratories, and its execution will be periodically evaluated according to international rules, employing as far as possible technical commissions and the mechanisms established to follow up programmes for international co-operation by CONICIT and COLCIENCIAS, including the help, if necessary, of international experts.

The manpower training and scientific exchange programme will embrace the usual activities in this area trying to harmonize the respective needs of the specific projects and, in more general terms, the goals of a programme for integrative development of biotechnology. To that effect, mechanisms to ease the research exchange between Colombia and Venezuela will be established, and also the use of courses and training programmes of common interest.

The three subprogrammes will be run by an 'ad hoc' sharing Committee created by CONICIT and COLCIENCIAS and will oversee the accomplishment of objectives and the attribution to each sub-programme of the necessary resources.

The Biotechnology Programme of THE ANDEAn Corporation For DEVELOPMENT (CAF)

In order to contribute to the development of biotechnology in the countries of the Andean Group, through support to the research areas and spurring the creation of structures which will permit to link research results to the producing activity, the Andean Corporation for Development adopted a programme that will enable:

a) To promote communication among specialized research centres and to stimulate the exchange and harmonization of research and information.

b) To back the development of specific projects of applied research with the purpose to settle the ground for a more self-sustained development.

c) To support the constitution of operative structures that will bridge research sectors and users. (For instance, facilitating the association of research groups, farming centres and private enterprises.)

d) To support the establishment of enterprises specialized in the culture, propagation and commercialization of plants obtained by biotechnology applications.

e) To organize programmes for the education and training of the personnel, to ease technology transfer and advisory.

In the first phase, the programme will concentrate on the tissue culture area.

Selected research centres or companies carrying out or conceiving biotechnology projects will be supported. Choice or selection of projects will basically depend on the degree of their practical use.

Support will include personnel training and specialization, as well as technical assistance and consulting services. It will also include the equipment and the supply of research material. Concerning training and equipment areas, an important task has been planned: the search of support of international organisms in order to reinforce the CAF possible contributions.

At later stages, and after evaluation of the initial actions, new areas of biotechnology and genetic engineering will be introduced according to applicability and utility criteria.

The programme is expected to carry out the following main activities:

1. The establishment of an inventory of the subregional capacity in biotechnology, including:

a) Research areas.

b) Availability of laboratories. 
c) Availability and needs of skilled personnel.

d) Degree of application and present and potential use of biotechnology in the productive sector.

2. Selection or choice of programmes or projects, actual or in course of preparation.

3. Organization and outset of the projects.

4. Organization of a specialized seminar at subregional level.

5. Intervention before international organisations to obtain support on personnel training, consulting services and equipment.

6. Evaluation of the programme's results after the first year of operation.

The program will last two years and cost US\$1.0 million that will finance the following activities:

a) Inventory of the subregional capacity in the biotechnological sector.

b) Further development and identification of biotechnology programmes or projects.

c) Organization of meetings and specialized seminars at subregional level.

d) Promotion of participation of specialized international agencies in the programme.

e) Budget support to specialized centres on biotechnology in each country of the subregion.

The programme will be financed with resources of the Fund for Development of Genetic Engineering and Biotechnology in the Andean Group. The Assembly of Shareholders of the Andean Council for Development (CAF) has been urged to create the above mentioned fund, and to grant it US\$1.0 million from the accumulated net income of the CAF on the 31 st December 1986

The programme will be conducted by a unit specially created to that effect and composed of the Head of the Programme, one or several consultants, according to needs, supplied without any cost for CAF by specialized governmental or international agencies, and a secretariat.

\subsubsection{Andean-European Co-operation on Biotechnology}

A future Andean-European Co-operation in the biotechnology sec-tor may rely on the Agreement for Co-operation signed by both integration groups. To that effect, it is convenient to identify the main points of the above mentioned Agreement.

The Agreement has a global and integrative conception of cooperation which is defined as 'a broad economic co-operation to contribute to the development of the Parties respective economies and to raising their standards of living'. It is no longer something as punctual as the supports the EEC was offering to certain sectors in the past. The Agreement's global task is to spur more adequate stages according to the degree of maturity of both integration processes: it opens an ambitious outlook with far-reaching effects.

A 'more equitable distribution' of development potentials encloses a redistributive criterium maintained by the Andean Group and must lead to the planning of operation in which science and technology transfer would play an important role; and this because of the arrangements and commitments for teaching and transmission stated in the Agreement. The Agreement must therefore serve as an ambitious instrument for redistribution at subregional level.

To recognize that the Andean Group is made up of developing countries, and within it of less-developed countries, is to give to Bolivia and Ecuador a special treatment, above all in the education and training.

The co-operation for development enunciated in the GRAN/EEC Agreement recognizes the necessity to co-ordinate EEC member states efforts to back integration projects, in the present case scientific and technological. For the Andean Group it implies a larger capacity of harmonization and concertation so as to enable the integration projects to seize major opportunities which will probably be carried out by means of the European effort for co-ordination. The resulting rationalization should be considered as a growing and profitable potential which will depend on a more active and efficient position of the Andean Group during the execution of the Agreement.

Scientific and technological co-operation was sometimes confined to certain activities with detriment to others, to public agents 
disadvantaging the private sector. The Agreement explicitly embraces co-operation in the fields of science and technology, industrial development, agro-industry and farming, mining, fisheries, infrastructure, transport and communications, energy and tourism. The possibility to form joint ventures was not considered by the GRAN/EEC co-operation in the past. This leads to the necessity of seeking synergetic effects. Science and technology, as proposed by the An-dean strategy, must be the common denominator to all the sectors affected by modernization processes within the framework of the Andean Strategies for Science and Technology. Knowledge becomes the key to the whole integration process in various areas.

\section{Concluding Remarks}

a) We face an Agreement whose potential must be ambitious in its far-reaching effects. It may be used, within the present crisis, to transfer of knowledge and capacity necessary for the Andean Group for a more self-sustained development.

b) It is important to point out mechanisms or tools from the GRAN/EEC Agreement to make viable the knowledge and capacity transfer, and realized through the co-operation above indicated or in exclusively detailed activities.

c) The Agreement requires an explicit and feasible action framework for scientific and technological co-operation.

d) Completing this idea, a strong support would be given to the relationship of horizontal co-operation among the GRAN member countries in order to create a joint action through resources, capacities and abilities from the EEC.

The GRAN and EEC Member States must come to understand each other's experiences in science and technology. Priority is placed on the better understanding of the rationalization and canalization of recent resources in order to create a new and more integrative cooperation scheme.

GRAN is stepping towards a scheme of harmonization and concertation of needs and will, soon be ready to initiate this task. The subregion's 'harmonized' demands are already known, particularly in the subregional personnel education and training area which could become one of the most important channels for capacity transfer from the EEC to GRAN.

An unavoidable subject which has been discussed for a certain time by the GRAN member countries and in consequence has been approved as a Special Fund by Decision 183, is the organization and setting up of a financial mechanism to support joint actions. The precise identification of mechanisms for co-operation will come to light from the experiences and opinions exchanged during the European/Latin-American Seminar. 